\title{
Seasonal Variation in Mineral Nutrient Concentration of Primocane and Floricane Leaves in Trailing, Erect, and Semierect Blackberry Cultivars
}

\author{
Bernadine C. Strik ${ }^{1,3}$ and Amanda J. Vance ${ }^{2}$ \\ Department of Horticulture, Oregon State University, 4017 ALS, Corvallis, \\ OR 97331
}

Additional index words. Rubus, tissue nutrient concentration, leaf sampling, nutrient management

\begin{abstract}
Floricane-fruiting blackberry (Rubus L. subgenus Rubus, Watson) cultivars, 'Marion', 'Black Diamond', 'Onyx', 'Columbia Star' (early-season trailing types), 'Ouachita' (erect, midseason), and 'Triple Crown' and 'Chester Thornless' (semierect, late season) were studied for 2 years to determine whether these cultivars and types of blackberry should be sampled at a certain stage of development or time of season to best evaluate plant nutrient status. Leaf nutrient standards are based on primocane leaves in most countries, but there is interest in using floricane leaves. Primocane leaves were sampled every 2 weeks from late May through early October, whereas leaves on fruiting laterals (floricane) were sampled every 2 weeks from early May through fruit harvest. Leaves were analyzed to determine the concentration of macronutrients and micronutrients. The pattern of change in primocane leaf nutrient concentration varied between the trailing and the later-fruiting erect and semierect types, particularly for $\mathrm{P}, \mathrm{K}, \mathrm{Ca}, \mathrm{Mg}, \mathrm{B}$, and $\mathrm{Mn}$, where leaf levels were higher in the late season for the erect and semierect cultivars (except for $P$ and $K$ which were lower). Nutrient concentrations in floricane leaves decreased during growth and development of the lateral and fruiting season for $\mathrm{N}, \mathrm{P}, \mathrm{K}$, and $\mathrm{S}$, but increased for most other nutrients in all blackberry types. Floricane leaf $\mathrm{N}$ and $\mathrm{K}$ declined most rapidly during the fruit development period in all cultivars. Sampling of floricane leaves is not recommended, particularly for trailing types, as there are no sufficiency standards. In primocane leaves, the nutrients that did not show significant changes in concentration during the currently recommended sampling period of late July to early August were N, Mg, K, Ca, S, B, Mn, and Zn, but only in 2014. Leaf $P, F e$, and $A I$ were stable during this period in both years. In contrast, when sampling in mid to late August, leaf $\mathrm{N}, \mathrm{Mg}, \mathrm{Fe}, \mathrm{Mn}$, and Al were stable in both years and leaf $\mathrm{K}, \mathrm{Ca}, \mathrm{S}, \mathrm{B}, \mathrm{Cu}$, and $\mathrm{Zn}$ were stable in one of the 2 years. We thus propose changing the recommended sampling time to mid to late August for these diverse blackberry cultivars. The current sufficiency standards for primocanes did not encompass the blackberry types and cultivars studied here, suggesting the standards may need to be revised for this region.
\end{abstract}

About 6000 ha of blackberry (Rubus L. subgenus Rubus, Watson) were harvested in the United States in 2012 , with $42 \%$ of this production located in Oregon (U.S. Department of Agriculture, 2014). Oregon is the leading producer of trailing blackberry in the United States but also produces erect and semierect types for the fresh market. The growth habit and fruiting season of trailing, erect, and semierect blackberry differ considerably (Strik and Finn, 2012). In Oregon,

Received for publication 23 Mar. 2017. Accepted for publication 28 Apr. 2017.

The authors appreciate the valuable assistance of Cliff Pereira, Research Associate, Department of Statistics, OSU and funding provided by the Oregon Raspberry and Blackberry Commission. ${ }^{1}$ Professor.

${ }^{2}$ Faculty Research Assistant.

${ }^{3}$ Corresponding author. E-mail: bernadine.strik@ oregonstate.edu. based on general guidelines for nitrogen $(\mathrm{N})$ fertilizer, in which rates increase from the planting year to maturity (Hart et al., 2006). Adjustments of fertilizer $\mathrm{N}$ and other macronutrients and micronutrients are based on the periodic soil nutrient analysis, observations of plant growth, and annual leaf tissue analysis (Bolda et al., 2012; Bushway et al., 2008; Fernandez and Ballington, 1999; Hart et al., 2006; Krewer et al., 1999). In floricanefruiting blackberry and raspberry, leaf sampling of primocanes in mid to late-season informs growers of plant nutrient requirements for fruit production the following season, when the primocane becomes a floricane.

Leaf sampling for tissue nutrient analysis is recommended for primocanes from May to August (Bolda et al., 2012), "following harvest" (Fernandez and Ballington, 1999), the first week of August (Bushway et al., 2008), or late July to early August (Hart et al., 2006). The recommended nutrient sufficiency levels are similar among these currently available nutrient management guides and all have the same standards and sampling time recommendations regardless of the blackberry type. Strik (2015) recommended that primocane-fruiting blackberry be sampled at the early green-fruit stage (about 8 weeks after summer pruning) than a particular calendar date and suggested the leaf sufficiency range for phosphorus $(\mathrm{P})$ and potassium (K) may need to be lowered for this crop.

Primocane leaf nutrient levels have been shown to vary over the growing season in erect (Clark et al., 1988) and trailing (Mohadjer et al., 2001) floricane-fruiting blackberry, primocane-fruiting blackberry (Strik, 2015), and floricane-fruiting raspberry (Hughes et al., 1979; John and Daubeny, 1972; John et al., 1976; Kowalenko, 1994; Wright and Waister, 1980). Although floricane leaves in blackberry have been shown to change over the fruiting season, standards for this leaf tissue type have only been developed in Brazil (Pereira et al., 2015).

Cultivars of blackberry (FernandezSalvador et al., 2015a, 2015b, 2015c; Dixon et al., 2016; Harkins et al., 2014; Strik, 2015) and raspberry (John and Daubeny, 1972; John et al., 1976) differed in primocane leaf nutrient levels when sampled in midseason. By contrast, Clark et al. (1988) found no difference among three erect blackberry cultivars in leaf nutrient levels and speculated that this was because of their similar parentage.

The objective of this study was to evaluate the impact of sample date on primocane leaf nutrient concentration in trailing, erect, and semierect blackberry cultivars with a goal of establishing the ideal sampling time for these crops. In addition, we studied the impact of sampling time during fruiting lateral development and fruiting on the nutrient concentration in the floricane to assess whether this might offer an alternative sampling method in these types of blackberry. 


\section{Materials and Methods}

Study site. The study was conducted in 2013 and 2014, in a mature planting at Oregon State University's North Willamette Research and Extension Center, Aurora, OR [lat. $45^{\circ} 16^{\prime} 47^{\prime \prime} \mathrm{N}$, long. $122^{\circ} 45^{\prime} 23^{\prime \prime} \mathrm{W}$; USDA hardiness zone 8b (U.S. Department of Agricultural Research Service, 2014); the weather records for this site can be viewed at U.S. Department of Interior (2014)]. The soil is mapped as a Willamette silt loam, classified as a fine-silty, mixed, superactive, mesic, Pachic, Ultic, and Argixeroll.

Plants were established in Spring 2010 except for 'Triple Crown' (planted Oct. 2010) and 'Columbia Star' (planted Sept. 2011 ) at $1.5 \mathrm{~m}$ in the row with $3 \mathrm{~m}$ between rows (2222 plants/ha). A permanent grass cover crop grew between the rows. The inrow area was maintained (bare soil) with preemergent herbicides and hoeing, as needed. Plants were irrigated with a single line of drip tubing (UniRam; Netafim USA, Fresno, CA) containing pressurecompensating emitters (1.9 L. $\mathrm{h}^{-1}$ in-line) spaced every $0.6 \mathrm{~m}$.

Soil testing. Soil samples were collected on 12 Nov. 2013 and 21 Oct. 2014 using a $2.4-\mathrm{cm}$ diameter, $0.5-\mathrm{m}$ long, slotted, openside, chrome-plated steel soil probe (Soil Sampler Model Hoffer; JBK Manufacturing, Dayton, $\mathrm{OH})$. Soil was sampled to a depth of $0.3 \mathrm{~m}$ at the center of the row, $\approx 0.3 \mathrm{~m}$ from the crown between plants and within the water emitter drip zone or fertilization area. A pooled sample was collected for the site (not replicated) and was sent for analysis of macronutrient and micronutrient concentration and $\mathrm{pH}$ to Brookside Laboratories Inc. (New Bremen, OH) (Table 1).

Cultivars. Four trailing blackberry cultivars ('Black Diamond', 'Columbia Star', 'Marion', and 'Onyx'), one erect type ('Ouachita'), and two semierect types ('Chester Thornless' and 'Triple Crown') were studied.

Production system. The trailing cultivars were grown in an alternate year production system (Strik and Finn, 2012), but only plants in the fruiting or "on year" were sampled in 2013 and 2014. Plants were trained on a two-wire vertical trellis system in each row with the wires attached to steel posts at 1.0 and $1.6 \mathrm{~m}$ above the ground. New primocanes were trained along the ground in the row, under the floricane canopy during the growing season, per standard practice. In the erect and semierect blackberry cultivars, primocanes were tipped at a height of $\approx 1.0-1.5 \mathrm{~m}$ per standard practice to encourage branching. Floricanes were removed in autumn (after they had senesced). Primocanes were then trained to the same two-wire vertical trellis system as the trailing cultivars by wrapping and tying as necessary. Primocane branches were pruned to $1 \mathrm{~m}$, in winter, as needed.

Fertilizer nutrients were applied per standard recommendations (Hart et al., 2006) and using results from soil analysis (Table 1). In 2013, $79 \mathrm{~kg} \cdot \mathrm{ha}^{-1} \mathrm{~N}$ was applied in a split application with $34 \mathrm{~kg} \cdot \mathrm{ha}^{-1}$ on 3 Apr. $(8 \mathrm{~N}-7.5 \mathrm{P}-14 \mathrm{~K})$ and $45 \mathrm{~kg} \cdot \mathrm{ha}^{-1}$ on 28 May (40N-0P-0K-5Mg). In 2014, $90 \mathrm{~kg} \cdot \mathrm{ha}^{-1} \mathrm{~N}$ was applied in two equal portions on 27 Mar. and 5 June $(16 \mathrm{~N}-7 \mathrm{P}-$ $13 \mathrm{~K})$. An additional $28 \mathrm{~kg} \cdot \mathrm{ha}^{-1} \mathrm{~N}$ was applied to erect and semierect cultivars on 7 July 2014 (16N-7P-13K). These granular fertilizers were broadcast within the in-row area and were washed into the soil through rainfall (data not shown). Copper fungicide (Nu-Cop; Albaugh Inc., Ankeny, IA) was applied to all plants $\left(0.4 \mathrm{~kg} \cdot \mathrm{ha}^{-1}\right.$ of $\left.\mathrm{Cu}\right)$ on 24 Mar. 2014 to control the cane diseases purple blotch [Septocyta ruborum (Lib.) Petr.] and cane rust [Kuehneola uredines (Link) Arthur].

Leaf sampling. Tissue samples for nutrient testing were collected approximately every 2 weeks by choosing the most recent fully expanded leaves on primocanes (20-21 May to 6-7 Oct. 2013 and 2014) and floricane laterals (trailing: 6-7 May to 28-29 July; erect and semierect: 6-7 May to 6-7 Oct. 2013 and 2014) for a total of 11 samples in each year for primocanes (Table 2). 'Black Diamond' and 'Ouachita' primocanes grew earlier in the spring and were thus sampled 2 weeks before those of the other cultivars. Stages of plant development and fruiting season were recorded and are presented in Table 2. The rate of plant development and fruiting season did not appear to differ between years (data not shown). Yield data were not recorded, but the field was observed to have a good, typical commercial yield for these cultivars in Oregon.

About 6 or 12 of the most recent, fully expanded primocane and fruiting lateral leaves, respectively, including petioles, were sampled per plot on each date and were left unwashed per standard recommendation (Hart et al., 2006). Sampled leaves were priority shipped to Brookside Laboratories for analysis. Leaf $\mathrm{N}$ was determined using a combustion analyzer with an induction furnace and a thermal conductivity detector (Gavlak et al., 1994). Other nutrients, including $\mathrm{P}, \mathrm{K}$, calcium $(\mathrm{Ca})$, magnesium $(\mathrm{Mg})$, aluminum $(\mathrm{Al}), \mathrm{B}$, copper $(\mathrm{Cu})$, manganese $(\mathrm{Mn})$, iron $(\mathrm{Fe})$, and zinc $(\mathrm{Zn})$ were determined using an inductively coupled plasma spectrophotometer after wet ashing the samples in nitric/perchloric acid (Gavlak et al., 1994).
Data analysis. The treatments were arranged in a completely random design with three replicates of three-plant plots. Data were analyzed by tissue type (primocane or floricane) separately, as our goal was not to compare canes, but to determine changes in leaf nutrient concentration over the sampling period and assess optimal sampling times. In addition, there is evidence that floricanes and primocanes are independent in blackberry (Bryla and Strik, 2008). On each sample date, leaf nutrient data were first analyzed for the effect of year and cultivar using PROC MIXED (SAS version 9.3) with year as the main effect $(n=2)$ and cultivar as the subplot effect $(n=4)$ with a Satterthwaite approximation used, as needed, for main effect comparisons.

Three sample dates (from late July to late August) that bracketed the recommended tissue nutrient sampling time for blackberry in our region (Hart et al., 2006), were analyzed to determine the effect of year, cultivar, and sample date. Mean comparisons were performed using least-square means. Contrasts were used to determine differences between early- and late-fruiting types (trailing vs. erect and semierect) as well as differences between erect and semierect types during this period.

PROC UNIVARIATE and the ShapiroWilk procedure were used to assess normality of the data for all the aforementioned analyses. As the tissue concentration of many nutrients was not normally distributed, a $\log$ transformation was used to improve homogeneity of variance and to assess proportional effects. Data were back transformed for presentation.

\section{Results and Discussion}

Rate of development and fruiting season. Key phenological stages and fruiting season are presented for the cultivars studied for each tissue sample date (Table 2). There were no observed differences among key phenological stages between years (data not shown). The trailing cultivars Black Diamond, Columbia Star, Marion, and Onyx had the earliest fruiting seasons, followed by the erect cultivar Ouachita and then the semierect cultivars Triple Crown and Chester Thornless (Table 2).

Year effect. There was a significant main effect of year on primocane leaf nutrient concentration of the cultivars studied on many sample dates through the season for all nutrients (data not shown). In general, the concentration of $\mathrm{N}, \mathrm{S}, \mathrm{B}, \mathrm{Fe}$, and $\mathrm{Al}$ was higher and that of $\mathrm{P}, \mathrm{Mg}, \mathrm{K}, \mathrm{Ca}, \mathrm{Mn}$, and $\mathrm{Cu}$ was lower on one or more sample dates in 2013 than in 2014.

Table 1. Soil nutrient pH, organic matter content, and nutrient levels when sampled in Nov. 2013 and Oct. 2014 at Oregon State University's North Willamette Research and Extension Center, Aurora, OR (unreplicated).

\begin{tabular}{|c|c|c|c|c|c|c|c|c|c|c|c|c|c|c|c|}
\hline $\mathrm{Yr}$ & $\mathrm{pH}$ & Organic matter $(\%)$ & \multicolumn{13}{|c|}{ Ppm } \\
\hline 2014 & 5.8 & 3.1 & 5.5 & 4.2 & 278 & 312 & 1159 & 284 & 22 & 0.43 & 365 & 35 & 8.8 & 3.9 & 1296 \\
\hline
\end{tabular}

${ }^{\mathrm{Z}} \mathrm{P}$ tested using Bray I method (Brookside Laboratories Inc., New Bremen, OH). 


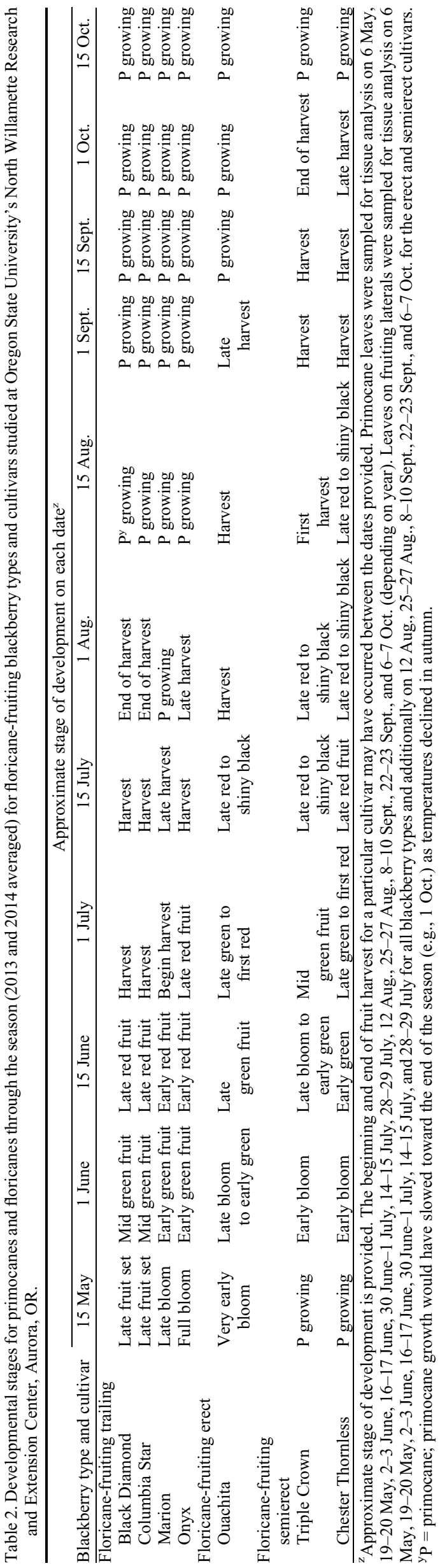

There was an effect of year on floricane leaf nutrient concentration of the cultivars studied on many sample dates for all the nutrients (data not shown). The concentrations of $\mathrm{K}, \mathrm{B}, \mathrm{Fe}, \mathrm{Zn}$, and $\mathrm{Al}$ were higher, whereas $\mathrm{N}, \mathrm{P}, \mathrm{Mg}, \mathrm{Ca}, \mathrm{S}$, and $\mathrm{Mn}$ were lower on at least one sample date in 2013 than in 2014.

The pattern of the change in primocane and floricane leaf nutrient concentration within each cultivar was relatively similar through the season between years (data not shown), but there was an effect of year and cultivar, and sometimes an interaction between year and cultivar found for several nutrients and sample dates. We have chosen not to show both years of data for seven cultivars and 11 primocane and 7 11 floricane sample dates. Instead, we are presenting data for the 2014 growing season to show the pattern of change over time. In Table 3, we present year by cultivar interactions for primocanes on select dates that bracket the range in current tissue nutrient sampling recommendations (Hart et al., 2006).

Primocane leaf nutrient concentration. There was a significant effect of cultivar on primocane leaf $\mathrm{N}$ concentration in early spring and toward the later part of the growing season (Fig. 1). 'Black Diamond', 'Columbia Star', 'Marion', and 'Onyx' had lower leaf $\mathrm{N}$ in mid-June than the erect and semierect cultivars, whereas 'Chester Thornless' and 'Triple Crown' had a higher and lower leaf $\mathrm{N}$, respectively, in the late summer and autumn. Leaf $\mathrm{N}$ declined from spring to summer in all the cultivars and was then variable ('Chester Thornless') or remained relatively stable (all others).

Leaf $\mathrm{P}$ declined through the season in 'Ouachita', 'Triple Crown', and 'Chester Thornless', whereas concentrations increased in late summer in most of the trailing cultivars to levels significantly higher than in the erect and semierect cultivars (Fig. 1). 'Onyx' was similar to the other trailing cultivars until midAugust when the $\mathrm{P}$ concentration in primocane leaves declined to levels similar to those measured in 'Chester Thornless'.

Leaf $\mathrm{K}$ concentration declined from spring to autumn in 'Ouachita' (except for one increase in late July) and 'Triple Crown', as was reported for primocanefruiting blackberry by Strik (2015), but in 'Chester Thornless' levels were the lowest in late summer. 'Columbia Star', 'Marion', and 'Black Diamond' had the highest leaf $\mathrm{K}$ concentration in late summer to autumn (Fig. 1), perhaps because the fruiting season was over in these cultivars (Table 2), although leaf $\mathrm{K}$ in 'Onyx' was highest in the spring.

Leaf $\mathrm{Mg}$ and $\mathrm{Ca}$ concentrations increased overall from spring to autumn in the erect and semierect cultivars, although levels did fluctuate during the summer, whereas in trailing cultivars levels were 






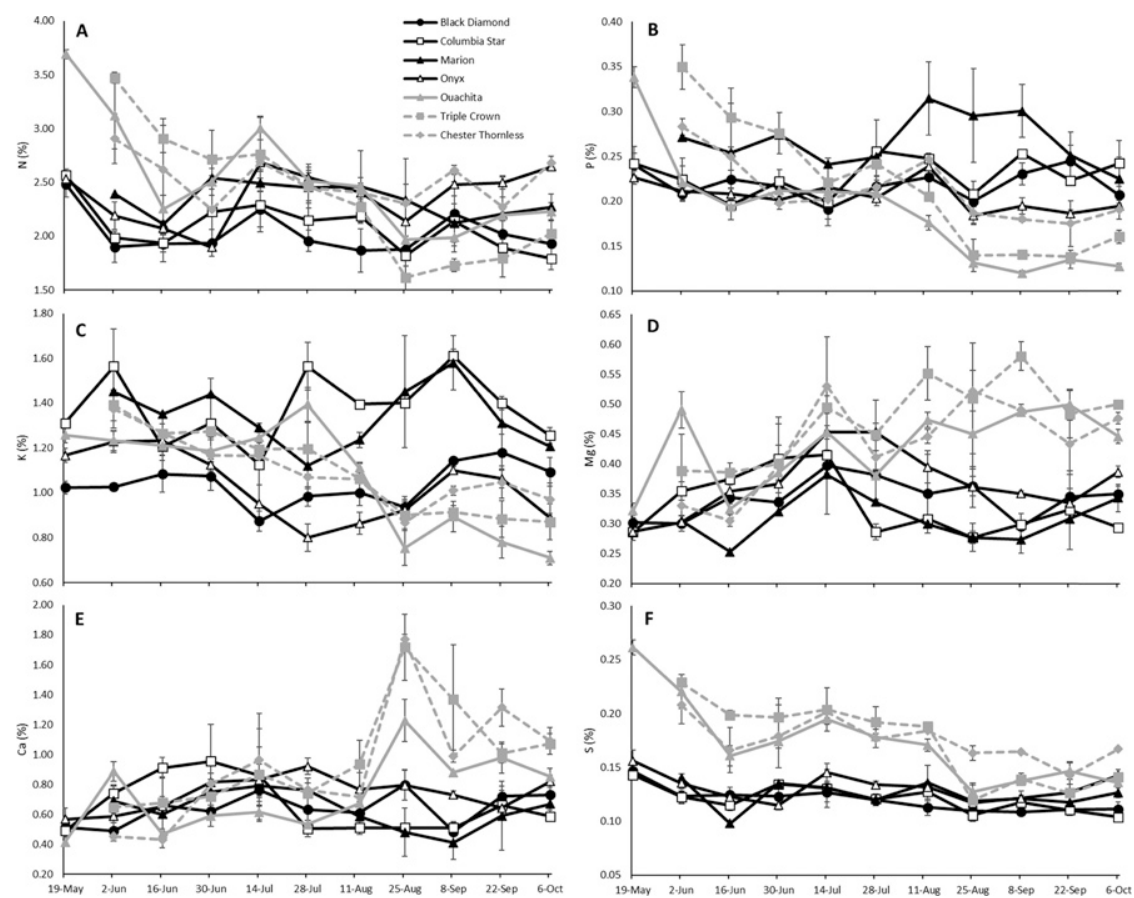

Fig. 1. The effect of sample date over the growing season on the concentration of macronutrients in primocane leaves of floricane-fruiting, trailing ('Black Diamond', 'Columbia Star', 'Marion', and 'Onyx'), erect ('Ouachita'), and semierect ('Chester Thornless' and 'Triple Crown') blackberry at the North Willamette Research and Extension Center, Aurora, OR, 2014. A = nitrogen; $\mathbf{B}=$ phosphorus; $\mathbf{C}=$ potassium $; \mathbf{D}=$ magnesium $; \mathbf{E}=$ calcium $; \mathbf{F}=$ sulfur. Bars indicate standard error for cultivar.
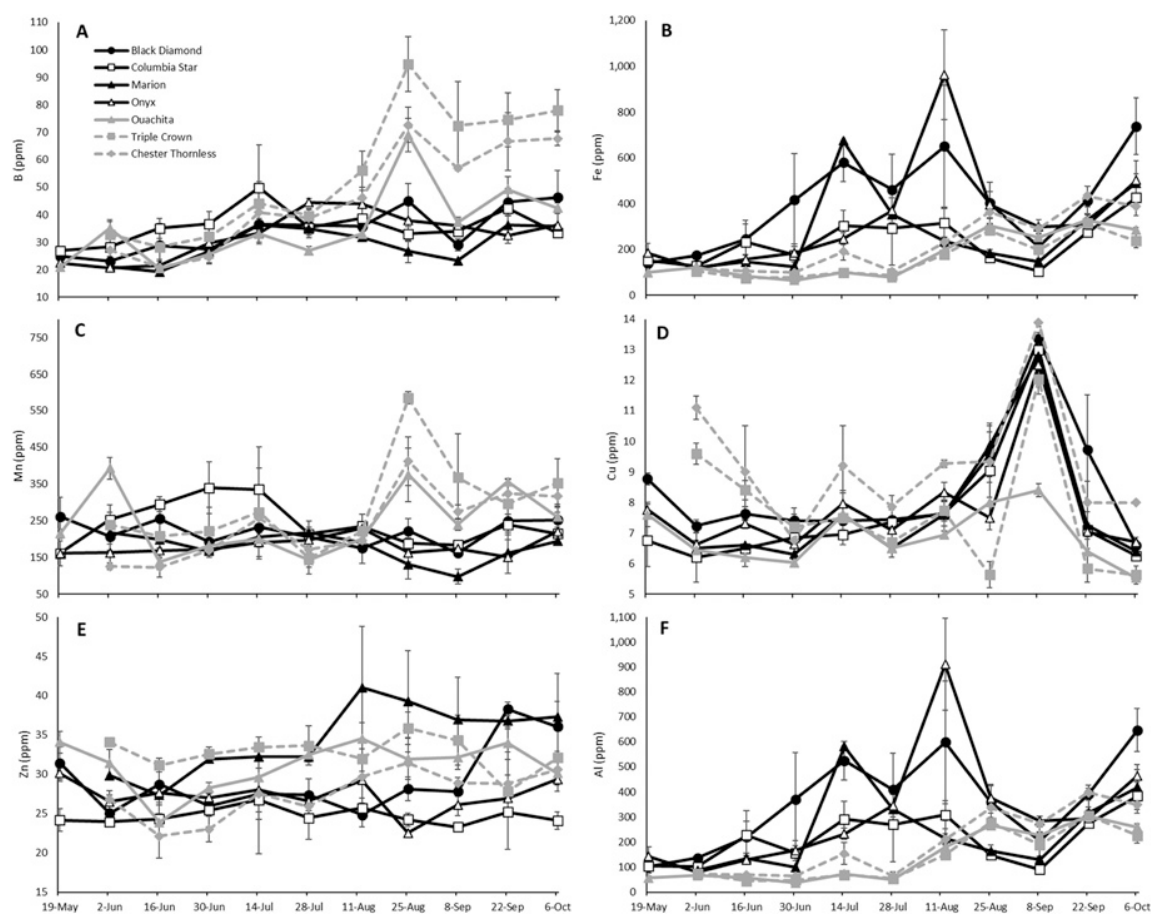

Fig. 2. The effect of sample date over the growing season on the concentration of micronutrients in primocane leaves of floricane-fruiting, trailing ('Black Diamond', 'Columbia Star', 'Marion', and 'Onyx'), erect ('Ouachita'), and semierect ('Chester Thornless' and 'Triple Crown') blackberry at the North Willamette Research and Extension Center, Aurora, OR, 2014. A = boron; $\mathbf{B}=$ manganese; $\mathbf{C}=$ iron; $\mathbf{D}=$ copper $\mathbf{E}=$ zinc $; \mathbf{F}=$ aluminum. Bars indicate standard error for cultivar.

relatively flat through the season and were lower in late summer. Peaks in leaf $\mathrm{Ca}$ concentration during the season may have been related to variability in leaf sampling caused by summer pruning (tipping) as reported for primocane-fruiting blackberry (Strik, 2015). The trailing blackberry cultivars had a considerably lower leaf S concentration than the erect and semierect cultivars, especially from spring to midsummer (Fig. 1).

The pattern of change in leaf B was similar amongst the blackberry cultivars in the spring to midsummer (Fig. 2). However, leaf B increased rapidly from late July to the end of August in the erect and semierect cultivars to levels significantly higher than in the trailing cultivars, particularly in 'Chester Thornless' and 'Triple Crown'. A similar pattern was observed for leaf $\mathrm{Mn}$. Leaf $\mathrm{Cu}$ was relatively stable in the early season except for the semierect cultivars, but increased for all cultivars except 'Ouachita' in the late season. Leaf $\mathrm{Zn}$ concentration generally increased through the season and was highest ('Marion') and lowest ('Columbia Star') in the trailing cultivars on many sample dates.

Primocane leaf $\mathrm{Fe}$ and $\mathrm{Al}$ concentrations were much higher in the trailing cultivars than the other blackberry types likely because there was dust (soil) on these leaves and leaves are not washed before tissue analysis (Hart et al., 2006); trailing blackberry primocanes are not self-supporting and were laying on the soil during the sampling period as opposed to the erect growth habit of 'Ouachita', 'Triple Crown', and 'Chester Thornless'.

Sampling time recommendations. The current tissue sampling recommendations for blackberry vary by region (Bolda et al., 2012; Bushway et al., 2008; Fernandez and Ballington, 1999; Hart et al., 2006). Sampling is recommended for a time when tissue nutrient concentrations are relatively stable to minimize variation. Rather than a specific date, Strik (2105) recommended that primocane-fruiting, erect blackberry cultivars be sampled at the bloom to green-fruit stage of growth. In the erect and semierect cultivars we studied, the only nutrients that appeared to have relatively stable concentrations in the late July to early August sampling period were N, K, $\mathrm{S}, \mathrm{Mn}, \mathrm{Zn}$, and $\mathrm{Cu}$ (Figs. 1 and 2). However, by late July to early August, some nutrients started to increase $(\mathrm{Ca}, \mathrm{Mg}, \mathrm{B}$, and $\mathrm{Al}$ ) or decrease (P) in concentration.

Tissue nutrient concentrations for the three primocane leaf sampling dates ranging from the end of July to late August of each year were compared for all cultivars (Table 3). We chose these dates to correspond to a range similar to what is currently recommended for sampling in our region (Hart et al., 2006). There was a significant year by sampling date interaction for all nutrients. When comparing sampling in late July to early August (dates 7 and 8 in Table 3), there was no sampling date effect for $\mathrm{N}, \mathrm{Mg}, \mathrm{K}, \mathrm{Ca}, \mathrm{S}, \mathrm{B}, \mathrm{Mn}$, and $\mathrm{Zn}$ (only in 2014); P, Fe, and $\mathrm{Al}$ in both years; primocane leaf $\mathrm{Cu}$ was not stable during this period in either year. However, when the sampling period was mid to late August (dates 8 and 9, Table 3), primocane leaf $\mathrm{N}, \mathrm{Mg}, \mathrm{Fe}, \mathrm{Mn}$, and $\mathrm{Al}$ were stable in both years, leaf $\mathrm{K}, \mathrm{Ca}, \mathrm{S}, \mathrm{B}, \mathrm{Cu}$, and $\mathrm{Zn}$ were stable in one of the years of study, 
whereas leaf $\mathrm{P}$ was not stable in either year.

Leaf $\mathrm{N}$ concentration declined from late July to mid-August, particularly in 2013 (Table 3), and leaf N, on average, was only within the current recommended sufficiency levels on the first sample date (both years). Leaf $\mathrm{P}$ was below current sufficiency levels on the first two sample dates in 2013, but was at the low end of the range on all dates. Average leaf $\mathrm{K}$ concentration was below current sufficiency levels on all sampling dates despite sufficient soil K (Table 1) and fertilization with $\mathrm{K}$ at recommended levels. Leaf $\mathrm{K}$ declined during the late July to late August sampling period in 2014 but only declined from late July to early August in 2013 before increasing again in late August (Fig. 1). Primocane leaf $\mathrm{Fe}$ and $\mathrm{Mn}$ were above recommended sufficiency levels on one or more later sampling dates (Table 3), perhaps because of the presence of dust on the leaves $(\mathrm{Fe})$ and a soil $\mathrm{pH}$ that was at the low end of the recommended range for blackberry (Hart et al., 2006). All of the other nutrients were within current sufficiency levels during the late July to late August sample period.

Cultivar had a significant effect on the nutrient concentration of primocane leaves when sampled from late July to late August (Table 3). The trailing cultivars had a lower average leaf $\mathrm{N}$ than the erect and semierect cultivars (which did not differ). There was a cultivar $\times$ date interaction, because leaf $\mathrm{N}$ in 'Onyx', 'Columbia Star', 'Triple Crown', and 'Ouachita' declined rapidly from mid to late August, whereas leaf N changed relatively little during this period in the other cultivars (Fig. 1). All cultivars except 'Chester Thornless' and 'Onyx' had an average primocane leaf $\mathrm{N}$ concentration below the current recommended standards (when sampling from late July to late August; Table 3).

Average leaf $\mathrm{P}$ was below current sufficiency levels in all cultivars in 2013 and in 'Ouachita' in 2014 (Table 3). Trailing cultivars had higher leaf $\mathrm{P}$ than the erect and semierect cultivars, whereas the erect cultivar, Ouachita, had a lower leaf $P$ than the semierect cultivars. Leaf $P$ increased during the early sampling period for 'Marion', 'Chester Thornless', and 'Onyx', whereas levels remained relatively stable or declined in the other cultivars (Fig. 1).

Leaf $\mathrm{Mg}$ concentration was lower in the trailing cultivars than the other types and was higher in the semierect cultivars than in the erect cultivar, Ouachita (Table 3). Although blackberry type did not affect leaf $\mathrm{K}$, there was a strong effect of cultivar. 'Columbia Star' had the highest leaf $\mathrm{K}$ and 'Black Diamond' and 'Onyx' the lowest, depending on year. All cultivars had a leaf $\mathrm{K}$ below the current sufficiency levels except for 'Columbia Star' and 'Marion' in 2014 (Table 3). Although there was no date $\times$ cultivar interaction during the late July to late August sampling period (Table 3 ), leaf $\mathrm{K}$ was higher in the late season for all trailing cultivars except 'Onyx' as compared with the erect and semierect cultivars that were still fruiting at this time (Fig. 1; Table 2). It is possible that uptake of $\mathrm{K}$ from the soil preferentially goes to the floricane during the fruiting period. On average, trailing cultivars had lower leaf $\mathrm{Ca}$ than erect and semierect cultivars and 'Ouachita' had a higher leaf $\mathrm{Ca}$ than the semierect cultivars (Table 3 ). There was a sampling date $\times$ cultivar interaction during the late July to late August period because leaf $\mathrm{Ca}$ increased from mid to late August in the erect and semierect cultivars considerably compared with the trailing cultivars (Fig. 1). Leaf $\mathrm{Ca}$ levels are affected by tipping date and resulting leaf age at sampling in erect blackberry (Strik, 2015).

The trailing blackberry cultivars had lower leaf $\mathrm{B}, \mathrm{Mn}$, and $\mathrm{Zn}$ and higher leaf $\mathrm{Fe}$ and $\mathrm{Al}$ than the erect and semierect cultivars from late July to late August (Table 3). The semierect cultivars had higher leaf $\mathrm{B}, \mathrm{Mn}$, and $\mathrm{Cu}$, but lower $\mathrm{Zn}$ than the erect cultivar Ouachita. Leaf B and Mn increased in the erect and semierect cultivars on the late August sample date relative to the trailing cultivars (Fig. 2). Leaf $\mathrm{Cu}$ was significantly lower in 'Triple Crown' than the other cultivars on the late August sample date (Fig. 2). 'Onyx' and 'Columbia Star' had a lower leaf Al than the other cultivars on the late August sample date (Fig. 2).

Based on current sufficiency levels and the pattern of leaf nutrient change over the season, we do not recommend sampling the late-fruiting floricane cultivars 'Ouachita', 'Triple Crown', or 'Chester Thornless' at a particular developmental stage as was suggested by Fernandez and Ballington (1999; "following harvest") or for primocanefruiting blackberries (Strik, 2015). The primocane leaf nutrient concentrations measured in this study were below the published recommended standards for blackberries (Bolda et al., 2012; Bushway et al., 2008; Fernandez and Ballington, 1999; Hart et al., 2006) for P and $\mathrm{K}$ (all regions), $\mathrm{N}$ (only in Oregon; Hart et al., 2006), and $\mathrm{Mg}$ and $\mathrm{S}$ (only in the northeastern United States; Bushway et al., 2008). Leaf Fe (all regions) and Mn (California and northeastern United States; Bolda et al., 2012; Bushway et al., 2008) were higher than current standards.

Floricane leaf nutrient concentration. The effect of cultivar on floricane (fruiting lateral) leaf tissue nutrient concentration over the 2014 growing season is shown in Figs. 3 and 4. Floricane leaf $\mathrm{N}$ concentration declined during the floricane season from earlyfruiting lateral development (6 May) through fruiting and early floricane senescence in all of the blackberry types and cultivars (Fig. 3). Nitrogen may have declined as N was mobilized to the developing fruit. Leaf $\mathrm{N}$ levels were similar to those reported for floricane leaves of 'Tupy' and 'Xavante' erect blackberry in Brazil (Pereira et al., 2015) and 'Black Diamond' and 'Marion' in Oregon (Dixon et al., 2016). The pattern of change in leaf $\mathrm{S}$ in the floricanes was similar to leaf $\mathrm{N}$ (Fig. 3).
Floricane leaf $\mathrm{P}$ declined rapidly in the early spring for all cultivars, but was then relatively stable from early June through floricane senescence, except in 'Marion' where leaf $P$ dropped from early to late July. 'Black Diamond' had the greatest leaf P in June and early July, whereas 'Chester Thornless' had a significantly higher leaf $P$ in the late summer than the other erect and semierect cultivars (Fig. 3).

Leaf $\mathrm{K}$ in the fruiting lateral declined from spring to summer in the early-fruiting trailing cultivars and the midseason erect cultivar Ouachita, whereas leaf $\mathrm{K}$ did not start declining much in the semierect cultivars until late July (Fig. 3) when fruit coloring began (Table 2). 'Black Diamond', 'Columbia Star', and 'Onyx' leaf K increased during the last 2 weeks of July just before the onset of senescence. Floricane leaf K concentrations were similar to those reported in other erect cultivars (Pereira et al., 2015) and in 'Black Diamond' (Dixon et al., 2016); however, leaf $\mathrm{K}$ for 'Marion' was higher in our study than what was previously reported by Dixon et al. (2016). Leaf K declined during fruiting likely because of the relatively high $\mathrm{K}$ content of blackberry fruit (Dixon et al., 2016; Harkins et al., 2014).

Floricane leaf $\mathrm{Mg}$ increased from spring to the beginning of the fruiting season in the erect and semierect cultivars, whereas leaf $\mathrm{Mg}$ stayed relatively stable in the earlyfruiting trailing cultivars (Fig. 3). There was a very similar pattern in leaf $\mathrm{Ca}$ for all types and cultivars studied with increasing levels through the season. The reason for the decline in leaf $\mathrm{Ca}$ in the floricanes of erect and semierect cultivars in late August is not clear, but this decline was not observed in 2013 for these cultivars (data not shown). Floricane leaf $\mathrm{Ca}$ and $\mathrm{Mg}$ concentrations likely increased through the season because these leaves were aging, as has been reported in older leaves of raspberry (Hughes et al., 1979) and blackberry (Strik, 2015), and there are relatively low concentrations of these nutrients in trailing blackberry fruit (Dixon et al., 2016; Harkins et al., 2014).

In general, leaf $\mathrm{B}, \mathrm{Mn}, \mathrm{Fe}$, and $\mathrm{Al}$ concentration increased during the floricane season, with the exception of lower values of leaf B and Mn for the erect and semierect cultivars either just after fruit harvest or during fruit harvest, respectively (Fig. 4). Leaf $\mathrm{Cu}$ concentrations decreased slightly in the early season, but increased and were more variable for the later-fruiting cultivars from August to October. Leaf $\mathrm{Zn}$ levels declined in May and then increased slightly or remained relatively stable during fruiting, depending on cultivar.

Nutrient sufficiency standards have not been developed for floricane leaves of any type of blackberry in North America. Because the nutrient concentration in floricane leaves of trailing cultivars just before fruit harvest (approximately mid-June to 1 July) was greater than published primocane leaf sufficiency levels (Hart et al., 2006) for most nutrients, floricane-specific standards would 

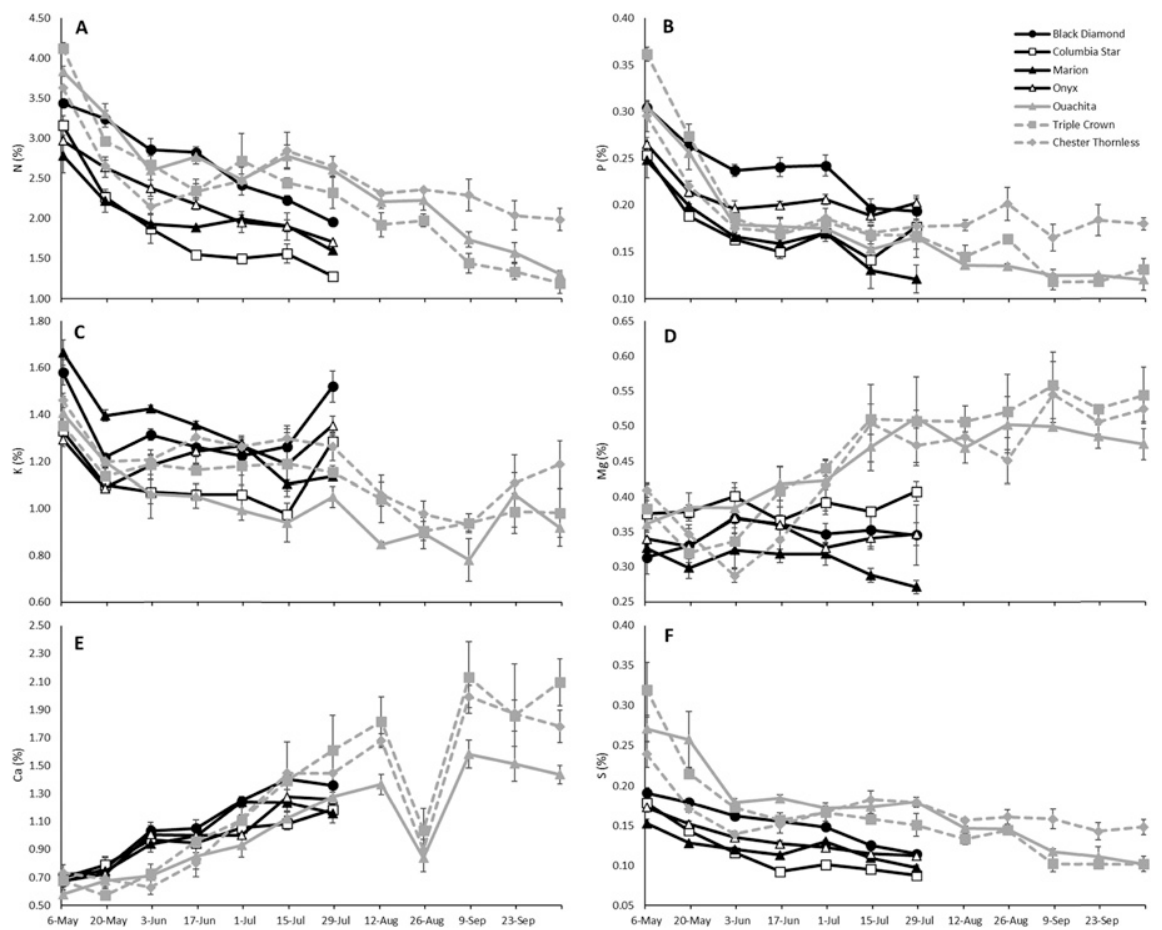

Fig. 3. The effect of sample date over the growing season on the concentration of macronutrients in floricane leaves of trailing ('Black Diamond', 'Columbia Star', 'Marion', and 'Onyx'), erect ('Ouachita'), and semierect ('Chester Thornless' and 'Triple Crown') blackberry at the North Willamette Research and Extension Center, Aurora, OR, 2014. A = nitrogen; $\mathbf{B}=$ phosphorus; $\mathbf{C}=$ potassium $; \mathbf{D}=$ magnesium $; \mathbf{E}=$ calcium $; \mathbf{F}=$ sulfur. Bars indicate standard error for cultivar.
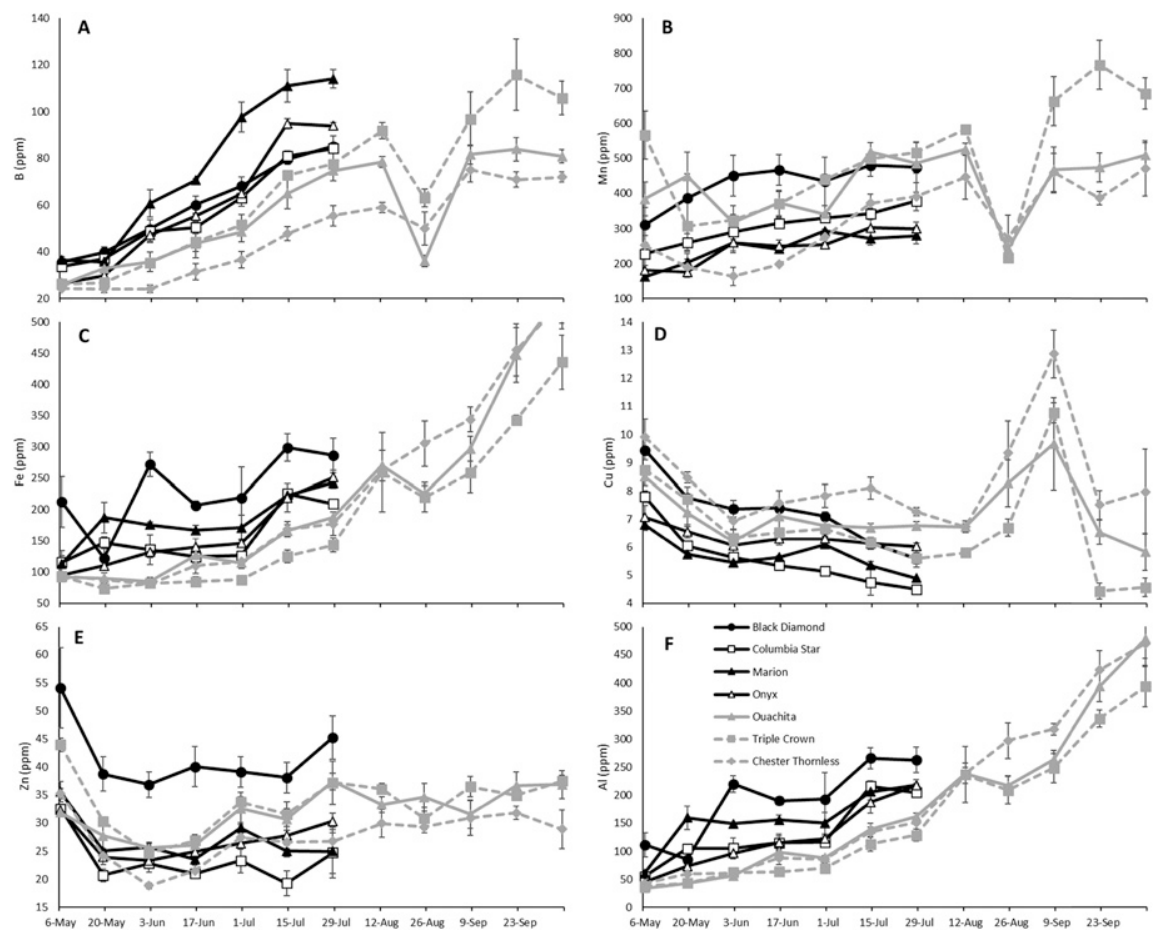

Fig. 4. The effect of sample date over the growing season on the concentration of micronutrients in floricane leaves of floricane-fruiting, trailing ('Black Diamond', 'Columbia Star', 'Marion', and 'Onyx'), erect ('Ouachita'), and semierect ('Chester Thornless' and 'Triple Crown') blackberry at the North Willamette Research and Extension Center, Aurora, OR, 2014. $\mathbf{A}=$ boron $\mathbf{B}=$ manganese $; \mathbf{C}=$ iron $\mathbf{D}=$ copper $\mathbf{E}=$ zinc $; \mathbf{F}=$ aluminum. Bars indicate standard error for cultivar. need to be developed. However, we do not recommend floricane leaves be used to manage fertilizer programs as the concentrations of most nutrients were rapidly changing during the lateral and fruit developmental period. By contrast, the floricane leaf concentrations of most nutrients in the erect and semierect cultivars were within the current primocane sufficiency levels (Table 3 ) when sampled in late July to early August (just before fruiting, Table 2), except for floricane leaf $\mathrm{K}$ (lower) and $\mathrm{Fe}$ and $\mathrm{Mn}$ (higher) (Fig. 4).

\section{Conclusions}

Our findings indicate that the growth habit or fruiting season (or both) of the three floricane-fruiting blackberry types as well as the cultivar grown affect primocane tissue nutrient concentrations. We thus recommend blackberry types and cultivars be sampled separately for tissue analysis. We do not recommend sampling floricane leaves to manage fertilizer programs in any blackberry type in North America, as standards for these diverse types have not been developed.

The currently recommended primocane leaf tissue sampling period of late July to early August (Hart et al., 2006) was not consistently ideal for all nutrients in these diverse blackberry cultivars. In our study, all nutrients except $\mathrm{Cu}$ were stable when sampling in the late July to early August period in 2014, but only P, Fe, and Al were stable during this period for both years. However, if sampling was delayed slightly, to mid to late August, more nutrients were stable during this period for both years of the study $(\mathrm{N}, \mathrm{Mg}$, $\mathrm{Fe}, \mathrm{Mn}$, and $\mathrm{Al}$ ). Considering leaf $\mathrm{N}$ is a key nutrient sampled to adjust fertilizer programs, we recommend shifting the recommended primocane sampling time to this slightly later period.

The primocane leaf nutrient concentrations measured in this study were below ( $\mathrm{P}$, $\mathrm{K}$, and $\mathrm{N}$ ) or above (Fe) current standards for our region (Hart et al., 2006). Our findings thus suggest that changing the sufficiency levels for these diverse blackberry types would aid growers in managing their fertilizer nutrient programs, as proposed by Strik and Vance (2016).

\section{Literature Cited}

Bolda, M., M. Gaskell, E. Mitcham, and M. Cahn. 2012. Fresh market caneberry production manual. Univ. Cal. Agr. Nat. Res., Pub. 3525.

Bryla, D. and B. Strik. 2008. Do primocanes and floricanes compete for soil water in blackberry? Acta Hort. 777:477-482.

Bushway, L., M. Pritts, and D. Handley (eds.). 2008. Raspberry \& Blackberry Production Guide for the Northeast, Midwest, and Eastern Canada. Plant and Life Sci. Pub. Coop. Ext., Ithaca, NY. NRAES-35.

Clark, J.R., J.B. Buckley, III, and E.W. Hellman. 1988. Seasonal variation in elemental concentration of blackberry leaves. HortScience 23:1080.

Dixon, E.K., B.C. Strik, and D.R. Bryla. 2016 Weed management, training, and irrigation 
practices for organic production of trailing blackberry: II. Soil and aboveground plant nutrient concentrations. HortScience 51:36-50.

Fernandez, G. and J. Ballington. 1999. Growing blackberries in North Carolina. North Carolina State Univ. Ext. Serv. Pub. AG-401. 15 Dec. 2016. <http://www.ces.ncsu.edu/depts/hort/hil/ pdf/ag-401.pdf $>$.

Fernandez-Salvador, J., B.C. Strik, and D.R. Bryla. 2015a. Liquid corn and fish fertilizers are good options for fertigation in blackberry cultivars grown in an organic production system. HortScience 50:225-233.

Fernandez-Salvador, J.A., B.C. Strik, and D. Bryla. 2015b. Response of blackberry cultivars to fertilizer source in an organic fresh market production system. HortTechnology 25:277-292.

Fernandez-Salvador, J., B.C. Strik, Y. Zhao, and C.E. Finn. 2015c. Trailing blackberry genotypes differ in yield and post-harvest fruit quality during establishment in an organic production system. HortScience 50:240-246.

Gavlak, R.G., D.A. Horneck, and R.O. Miller. 1994. Plant, soil and water reference methods for the western region. Western Region Ext. Pub. 125 (WREP-125), Univ. Alaska, Fairbanks, AK.

Harkins, R., B.C. Strik, and D. Bryla. 2014. Weed management practices for organic production of trailing blackberry.II. Accumulation and loss of biomass and nutrients. HortScience 49:35-43.
Hart, J., B.C. Strik, and H. Rempel. 2006. Caneberries. Nutrient management guide. Ore. State Univ. Ext. Serv., EM8903-E. 15 Dec. 2016. $<$ http://ir.library.oregonstate.edu/xmlui/bitstream/handle/1957/20427/em8903-e.pdf>.

Hughes, M., M.H. Chaplin, and A.R. Dixon. 1979 Elemental composition of red raspberry leaves as a function of time of season and position on cane. HortScience 14:46-47.

John, M.K. and H.A. Daubeny. 1972. Influence of genotype, date of sampling, and age of plant on leaf chemical composition of red raspberry (Rubus idaeus L.). J. Amer. Soc. Hort. Sci. 97:740-742.

John, M.K., H.A. Daubeny, and H.H. Chuah. 1976. Factors affecting elemental composition of red raspberry leaves. J. Sci. Food Agr. 27:877-882.

Kowalenko, C.G. 1994. Growing season changes in the concentration and distribution of macroelements in Willamette red raspberry plant parts. Can. J. Plant Sci. 74:833-839.

Krewer, G., B. Smith, P. Brannen, and D. Horton. 1999. Commercial bramble culture. Coop. Ext Serv. Univ. Georgia, Bull. 964. 15 Dec. 2016. $<$ http://www.smallfruits.org/Bramble/production/ BRAMBLE.pdf $>$.

Mohadjer, P., B.C. Strik, B.J. Zebarth, and T.L. Righetti. 2001. Nitrogen uptake, partitioning and remobilization in 'Kotata' blackberries in alternate year production. J. Hort. Sci. Biotechnol. 76:700-708.
Pereira, I.d.S., L. Picolotto, M.A. Gonçalves, G.K. Vignolo, and L.E.C. Antunes. 2015. Potassium fertilization affects floricane mineral nutrient content, growth, and yield of blackberry grown in Brazil. HortScience 50:1234-1240.

Strik, B.C. 2015. Seasonal variation in mineral nutrient content of primocane-fruiting blackberry leaves. HortScience 50:540-545.

Strik, B.C. and C.E. Finn. 2012. Blackberry production systems - A worldwide perspective. Acta Hort. 946:341-348.

Strik, B.C. and A.J. Vance. 2016. Leaf nutrient concentration in blackberry - recommended standards and sampling time should differ among blackberry types. Acta Hort. 1133: 311-317.

U.S. Department of Agricultural Research Service. 2014. Hardiness zone map. 9 Nov. 2016 $<$ http://planthardiness.ars.usda.gov/PHZMWeb/ InteractiveMap.aspx>

U.S. Department of Interior. 2014. Bureau of reclamation, Boise, ID. Agrimet Weather Station web site. 5 Dec. 2014. <www.usbr.gov/pn/ agrimet/agrimetmap/araoda.html $>$.

U.S. Department of Agriculture. 2014. Table 33: Berries: 2012 and 2007. In: 2012 Census of Agriculture. U.S. Dept. Agr., Natl. Agr. Statistical Serv., Washington, DC.

Wright, C.J. and P.D. Waister. 1980. Seasonal changes in the mineral nutrient content of the raspberry. Acta Hort. 112:295-304. 